\title{
Assays to Detect and Characterize Synthetic Agents that Inhibit the ErmC Methyltransferase
}

\author{
Joanna Clancy, Brenda J. Schmieder, Joan W. Petitpas, Mary Manousos, John A. Williams, \\ James A. Faiella, Arthur E. Girard and Paul R. MCGuirk \\ Central Research Division, Pfizer, Inc., \\ Groton, Connecticut 06340, U.S.A.
}

(Received for publication May 8, 1995)

\begin{abstract}
High throughput chemical file screening with an enzymatic assay to detect inhibitors of the ErmC methyltransferase enzyme from macrolide-lincosamide-streptogramin B $\left(\mathrm{MLS}_{\mathbf{B}}\right)$ resistant pathogenic bacteria identified low molecular weight compounds that had $\mathrm{IC}_{50 \mathrm{~s}}(50 \%$ inhibitory concentration) in the nMolar to $\mu$ Molar range. These same inhibitors were assessed in vitro for their capacity to inhibit the liver enzyme, cathechol- $O$-methyltransferase and the prokaryotic enzyme, EcoRI methylase. Selective inhibitors of the ErmC methyltransferase were tested in tertiary assays to determine their minimal inhibitory concentrations (MICs), as single agents and in combination with the macrolide, azithromycin, against strains of pathogenic bacteria expressing $\mathrm{MLS}_{\mathrm{B}}$-resistance. Compounds that were active in vitro, alone or in combination with azithromycin, against strains of macrolide-resistant pathogens were tested in a mouse model of infection using an MLS $_{\mathrm{B}}$-resistant strain of Staphylococcus aureus or a macrolide-susceptible strain of Streptococcus pyogenes.
\end{abstract}

Macrolide, lincosamide, and streptogramin $\mathrm{B}\left(\mathrm{MLS}_{\mathrm{B}}\right)$ antibiotics have distinct chemical structures but have been shown to have a similar mechanism of action against bacteria. They inhibit peptidyltransferase reactions in vitro and are inhibitors of peptide bond formation in whole cells ${ }^{1,2}$. The first macrolides, largely fermentation products, were narrow to medium-spectrum antibiotics with in vitro potency mainly against Gram-positive bacteria, including streptococci, staphylococci and some anaerobes. The lincosamide, clindamycin, was also used extensively against anaerobic bacteria. The newer macrolides, azithromycin and clarithromycin, are semisynthetic derivatives with expanded activities against certain Gram-negative bacterial species, especially Haemophilus influenzae and Neisseria gonorrhoeae. Resistance to these antibiotics emerged within a few years of their introduction as therapeutic agents. The most widespread mechanism of macrolide and lincosamideresistance in pathogenic bacteria results from a base-specific dimethylation of bacterial $23 \mathrm{~S}$ ribosomal RNA near or within the macrolide binding site such that antibiotics of the macrolide, lincosamide, or streptogramin B chemical classes now fail to bind. Bacterial cells with such modifications become insensitive to inhibitors of these chemical classes. This phenotype is designated $\mathrm{MLS}_{\mathrm{B}}$-resistance ${ }^{3,4)}$.

Specific dimethylation is achieved in the bacterial cell through the action of a family of closely related methyltransferases encoded by genes designated erm, for erythromycin-resistance methylase. There are at least eight classes of erm genes as determined by nucleic acid hybridization analyses and nucleotide sequence comparisons; they show a significant amount of amino acid identity, suggesting that they are derived from a common ancestor. The methylases from Gram-positive bacterial pathogens, for example, are more than $50 \%$ identical in amino acid sequence ${ }^{5)}$. Consensus primers to conserved regions of the erm methylase genes are sufficient to allow detection of all erm genes in populations of bacteria by the polymerase chain reaction ${ }^{6}$.

The ErmC enzyme has been most extensively characterized. It exists in solution as a $29 \mathrm{kDa}$ monomeric protein which, in the bacterial cell, is largely bound to ribosomes. Methylation in whole cells specified by several related Erm methylases (ErmC, ErmD, ErmAm, and ErmE) inhibits methylation in vitro by the ErmC methylase, suggesting that these enzymes modify the same site on RRNA $^{7}$. While there are few published studies of the effect of inhibitors, these enzymes, like many transmethylases, have an absolute requirement for the methyl donor, S-adenosyl methionine (AdoMet). Analogues of AdoMet such as adenosine and S-adenosylhomocysteine (SAH) are highly inhibitory ${ }^{8,9)}$. The ErmC methylase also appears to be highly specific for domains of its second substrate, the 23S rRNA. Studies suggest that the enzyme-23S rRNA complex has a dissociation constant of $4 \times 10^{-9} \mathrm{M}$ with a $\mathrm{k}_{\text {on }}$ and $\mathrm{k}_{\text {off }}$ of $4 \times 10^{6} \mathrm{M}^{-1} \mathrm{~s}^{-1}$ and $6.8 \times 10^{-2} \mathrm{~s}^{-1}$, respectively ${ }^{10}$. 
High throughput screening of synthetic compounds was initiated in order to detect specific inhibitors of the ErmC methylase that could be used in combination with a broad-spectrum macrolide antibiotic for treatment of infections caused by $M S_{\mathrm{B}}$-resistant pathogenic bacteria. Such a combination could be used in human populations against macrolide-susceptible and resistant bacteria to extend the efficacy of macrolide, lincosamide and streptogramin $\mathrm{B}$ antibiotics, in much the same way that $\beta$ lactam, $\beta$-lactamase inhibitor combinations are presently used. Such inhibitors were detected and their $\mathrm{IC}_{50 \mathrm{~s}}$ for the ErmC methylase determined, as was their selectivity for this, as opposed to two other transmethylation enzymes, the catechol- $O$-methyltransferase from rat liver and the EcoRI methylase from E. coli. Finally, their capacity to inhibit $\mathrm{MLS}_{\mathrm{B}}$-resistant pathogenic bacteria in vitro, and in some cases in vivo, was assessed.

\section{Materials and Methods}

\section{Chemicals and Other Reagents}

P11 cellulose phosphate fibrous cation exchanger (\#21111) for column chromatography was from Whatman. E. coli rRNA and dithiothreitol (DTT) were from Boehringer-Mannheim. 3,4-dihydroxybenzoic acid, sinefungin, and ethylene glycol-bis ( $\beta$-aminoethyl ether) $\mathrm{N}, \mathrm{N}^{\prime}$-tetraacetic acid (EGTA) were from Sigma. RNasin ribonuclease inhibitor ( $\# \mathrm{~N} 2111)$ was from Promega. Catechol- $O$-methyltransferase (COMT; EC 2.2.1.6; NEE-160) and [Methyl $\left.{ }^{3} \mathrm{H}\right]$ AdoMet; $(0.55 \mathrm{mCi} / \mathrm{ml}$; NET-155H) were from NEN. Plasmid BR322 was from Pharmacia. S-adenosyl methionine (AdoMet), PvuII, $E c o R I$, and EcoRI methylase were from New England Biolabs. Azithromycin (CP-62,993-42; lot \#17419-200$4 F$ ) was from the Pfizer pharmacy. Brain heart infusion broth (BHI) was from Remel, Lenexa, Kansas. CP and UK compounds were synthesized by standard methods at Pfizer Central Research, Groton, CT and Sandwich, U.K.

\section{Strains and Plasmids}

Bacillus subtilis BD170 (trpC2 thr-5), containing plasmid pE194 cop-6 a derivative of pE194 which carries a constitutive mutant of the erm $\mathrm{C}$ gene from $S$. aureus ${ }^{8,11}$ ) was used as a source of ErmC methylase. S. aureus $01 \mathrm{~A} 110$ and $01 \mathrm{~A} 129$ are clinical strains with the $\mathrm{MLS}_{\mathrm{B}}$-resistant phenotype. The former is constitutive and the latter, inducible to $\mathrm{MLS}_{\mathrm{B}}$-resistance with 14- and 15-membered macrolides. E. faecalis $03 \mathrm{~A} 1029$ is also an inducibly-resistant $\mathrm{MLS}_{\mathrm{B}}$-resistant clinical strain, while E. faecalis RH110 (Tn916 $4 \mathrm{E}$ ) and the Group B streptococcal strain COH31-46 (Tn9164E) were produced by transformation of clinical strains with a transposon carrying a constitutive $\mathrm{MLS}_{\mathrm{B}}$-resistance gene ${ }^{12)}$. E. coli V854 contains a plasmid which expresses constitutive
$\mathrm{MLS}_{\mathrm{B}}$-resistance ${ }^{13)}$. S. pyogenes 12384 was obtained from ATCC.

\section{Preparation of the ErmC Methyltransferase}

Cultures of BD170 (pE194 cop-6) were grown with erythromycin selection and enzyme was prepared as previously described ${ }^{7,8)}$. Briefly, cells from exponential cultures of this strain were washed once in a low salt buffer, passaged through a French pressure cell, and the cell-free extract digested with DNase. Ribosomes were separated by centrifugation, washed with high salt solutions, and the supernatant solution was dialyzed for 4 hours with several changes of fresh buffer. Magnesium acetate was omitted and the preparation was chromatographed on a phosphocellulose P11 column ${ }^{7}$. Active fractions were pooled and stored at $-70^{\circ} \mathrm{C}$.

\section{Erm Methyltransferase Assay}

Buffers and solutions were prepared with glass distilled DEPC-treated water. $10 \times$ reaction buffer containing $500 \mathrm{~mm}$ Tris- $\mathrm{HCl}$ ( $\mathrm{pH} 7.5$ ), $40 \mathrm{~mm} \mathrm{MgCl}_{2}$ and $400 \mathrm{~mm}$ $\mathrm{KCl}$ was frozen in $50 \mathrm{ml}$ aliquots. Each reaction was performed in a well of a 96-well microtiter plate containing $5.0 \mu \mathrm{l}$ of $10 \times$ reaction buffer, $5.0 \mu \mathrm{l}$ of $100 \mathrm{~mm}$ DTT, $0.025 \mu \mathrm{l}$ RNasin, $1.4 \mu \mathrm{l}$ rRNA, and $0.75 \mu \mathrm{l}$ $\left[{ }^{3} \mathrm{H}\right]$-AdoMet adjusted to $30 \mu \mathrm{l}$. Putative inhibitors were added in $10 \mu 1$ volumes. $10 \mu \mathrm{l}$ of enzyme stock was added. The reaction was incubated for 120 minutes at $37^{\circ} \mathrm{C}$ and cerminated by adding $150 \mu \mathrm{l}$ of cold $6.6 \%$ TCA to each well. The plates were chilled to $4^{\circ} \mathrm{C}$ for 30 minutes and harvested on a 96-well cell harvester (Skatron, Lier, Norway) using three ten-second wash cycles. The filters were dried in a $50^{\circ} \mathrm{C}$ drying oven for 45 minutes. TCAprecipitable counts on the filters were quantitated in a LKB beta-plate counter. Sinefungin, an AdoMet analogue, was used as a positive control. $\mathrm{IC}_{50 \mathrm{~s}}$ were determined by graphing percent inhibition, as compared to the 'no inhibitor' control, versus increasing concentrations of inhibitor.

\section{Catechol- $O$-methyltransferase Assay}

Inhibitory activity was determined in a reaction mixture consisting of $225 \mathrm{~mm}$ TES, pH 8.0, $10 \mathrm{~mm}$ EGTA, $2 \mathrm{~mm}$ DTT, $3 \mathrm{~mm}$ magnesium chloride, $0.2 \mathrm{~mm}\left[{ }^{3} \mathrm{H}\right]$ AdoMet, and $2 \mathrm{~mm} \mathrm{3,4-dihydroxybenzoic} \mathrm{acid.} 15 \mu \mathrm{l}$ of this mixture was added to each well of a microtiter plate. $12.8 \mu \mathrm{l}\left[{ }^{3} \mathrm{H}\right]$-AdoMet $[0.153 \mu \mathrm{Ci}], 15 \mu \mathrm{l}$ COMT $(0.16$ units) and $15 \mu 1$ inhibitor were added. A 'no enzyme' and a 'no inhibitor' well served as controls in each experiment. The reaction mixture was incubated, extracted and centrifuged as specified in the catechol- $O$-methyltransferase protocol (NEN). The product was quantitated with a Packard Tri-Carb Liquid Scintillation Analyzer. Sinefungin was used as a positive control.

EcoRI Methylase Assay

For each assay, $2.0 \mu \mathrm{l}(0.5 \mu \mathrm{g})$ linear pBR322 was added to $2.5 \mu \mathrm{l}$ of $320 \mu \mathrm{M}$ AdoMet in $5 \times$ methylase buffer 
$(250 \mathrm{~mm} \mathrm{NaCl}, 250 \mathrm{~mm}$ Tris- $\mathrm{HCl} \mathrm{pH} 8.0$ and $50 \mathrm{~mm}$ EDTA), $3.5 \mu$ lof inhibitor diluted to desired concentration, and $2.0 \mu \mathrm{l}(0.5 \mathrm{unit})$ of EcoRI methylase in a final volume of $10 \mu \mathrm{l}$. The assay tube was incubated at $37^{\circ} \mathrm{C}$ for 1 hour. A 'no inhibitor' and a 'no methylase' control were included in each assay. The reaction was terminated by heating to $65^{\circ} \mathrm{C}$ for 10 minutes. The pBR322 template DNA was digested with $E c o R I$ restriction endonuclease by standard methods. $17 \mu \mathrm{l}$ of $3 \times$ agarose gel buffer with $0.25 \%$ bromphenol blue and $3 \%$ glycero $^{14)}$ was added to each reaction tube. $20 \mu 1$ of this mixture was electrophoresed in a $1.0 \%$ agarose gel using $1 \times \mathrm{TAE}$ running buffer ${ }^{14)} .20 \mu \mathrm{l}$ of Hind III-digested $\lambda$ DNA was added to a separate well to serve as size marker. The samples were electrophoresed for 1 hour at $50 \mathrm{~mA}$ and the DNA samples were visualized by photography of ethidium bromide-stained gels. For this assay, complete inhibition of the methylation reaction resulted in the formation of two bands at $2.30 \mathrm{~Kb}$ and $2.06 \mathrm{~Kb}$, and no appearance of a $4.36 \mathrm{~Kb}$ band. No inhibition of the methylation reaction resulted in the complete inaccessibility of the EcoRI site on pBR322, and the appearance of a single band of $4.36 \mathrm{~Kb}$. Inhibition was measured as a decrease in the intensity of the $4.36 \mathrm{~Kb}$ linear band on a GDS 5000 UVP densitometer.

Minimum Inhibitory Concentrations of Test Compounds +1 -Azithromycin

\section{Preparation of Bacterial Strains}

Working stocks of each of the bacterial strains were prepared by growth of isolated colonies in BHI. The presence of desired phenotypes was confirmed. E. faecalis RH110 (Tn9164E) and Group B streptococcal strain COH31-46 (Tn9164E) were grown in $5 \mu \mathrm{g} / \mathrm{ml}$ erythromycin to select against loss of the macrolide-resistance phenotype, while $E$. coli V854 was grown in $10 \mu \mathrm{g} / \mathrm{ml}$ erythromycin. Frozen stocks were prepared by mixing $600 \mu \mathrm{l}$ of an overnight culture of each strain with $400 \mu \mathrm{l}$ of $50 \%$ glycerol. Replicate stocks were frozen at $-70^{\circ} \mathrm{C}$. $25 \mu \mathrm{l}$ of thawed working stock was inoculated into $10 \mathrm{ml}$ of $\mathrm{BHI}$ broth and incubated overnight at $37^{\circ} \mathrm{C}$ with shaking. E. faecalis RH110 (Tn9164E) and the streptococcal strain COH31-46 (Tn9164E) were grown in BHI with $5 \mu \mathrm{g} / \mathrm{ml}$ erythromycin. In the morning; strains were removed from the incubator and their turbidities at $\mathrm{A} 600$ were determined, using $\mathrm{BHI}$ as a blank. Each of these strains achieved turbidities of 0.3 to 0.5 under these conditions.

\section{Preparation of Microtiter Plates}

The MIC determinations were performed in microtiter plates, using a separate plate for each test compound. A Cetus Pro/Pette (Perkin-Elmer) was used to serially dilute the azithromycin in wells Al to $\mathrm{H} 1$ across the wells through column 7 . Test compounds were two-fold serially diluted in $\mathrm{BHI}$ in test tubes. With a multichannel pipettor, $50 \mu \mathrm{l}$ of the first dilution of test compound was added to A1 through A7. Additions were continued in this manner through well G7. One well was filled with $200 \mu \mathrm{l}$ BHI to serve as a media sterility control well. A second well was filled with $100 \mu \mathrm{l} \mathrm{BHI}$ and $100 \mu \mathrm{l}$ of the test strain to serve as a bacterial growth control. Additional wells contained $150 \mu \mathrm{l}$ BHI and $50 \mu \mathrm{l}$ of azithromycin or test compound stock solution as controls for compound and azithromycin sterility. Microtiter plates were either inoculated immediately or wrapped and frozen at $-70^{\circ} \mathrm{C}$.

\section{Inoculation of Strains into Microtiter Plates}

Bacteria were prepared as indicated above and diluted $1 / 1000$ in BHI. The diluted test strain was poured into a sterile trough or petri dish. A multichannel pipettor was used to introduce $100 \mu \mathrm{l}$ of this suspension to wells A1 through H8. $100 \mu 1$ of this inoculum was also added to the appropriate control wells (see above). The final inoculum in the wells was $2 \sim 7 \times 10^{5}$ viable cells $/ \mathrm{ml}$, as determined by dilution and plating. The plates were shaken for 3 to 5 minutes on a Sarstedt TPM-2 shaker at $500 \mathrm{rpm}$. They were incubated overnight (approximately 15 hours) in a $37^{\circ} \mathrm{C}$ incubator. The turbidity in each well was observed with a mirrored plate reader (Titertek). For each plate, the lowest concentration of azithromycin that produced no growth was scored as the azithromycin MIC. The MIC of the test compound was similarly defined. For the wells with test compound plus azithromycin, the MIC was considered to be the combination which contained the lowest total concentration that inhibited growth of the test strain. The control wells were observed for appropriate growth or absence of growth. The solvent control wells in these assays produced growth of test organisms comparable to the growth control well. Synergy in these assays was defined as a $\geq 2$ dilution difference between the MIC of azithromycin plus test compound as compared to the MIC of test compound or azithromycin alone ${ }^{15)}$.

\section{Acute Systemic Infections}

The acute systemic infections were produced by ip administration of bacterial challenge to CF1 (Charles River) mixed sex mice $(11 \sim 13 \mathrm{~g})$. The number of organisms injected was adjusted to provide an inoculum one to ten times the $\mathrm{LD}_{100}$. S. pyogenes ATCC 12384 was grown overnight at $37^{\circ} \mathrm{C}$ in $\mathrm{BHI}$ broth, appropriately diluted and administered as a suspension in BHI broth. $S$. aureus $01 \mathrm{~A} 129$ was grown overnight on BHI agar containing erythromycin $(5 \mu \mathrm{g} / \mathrm{ml})$, washed off with sterile phosphate buffered saline, adjusted to a standard turbidity and suspended in sterile $5 \%$ hog gastric mucin prior to administration to mice. Survival was recorded over a 4-day period and the $\mathrm{PD}_{50}$ calculated from data obtained from a dose range consisting of four different antibiotic concentrations in a two-fold ( $S$. aureus studies) or four-fold (S. pyogenes study) dilution series. Mice (10 per group) were treated subcutaneously at 0.5 and 4 hours 
after challenge. The $50 \%$ protective dose $\left(\mathrm{PD}_{50}\right)$ was expressed in $\mathrm{mg} / \mathrm{kg} / \mathrm{dose}$ and calculated by the probit method $^{16)}$.

\section{Results and Discussion}

Compounds of several structural types (Table 1) were shown to be potent inhibitors of the ErmC methyltransferase reaction, producing $\mathrm{IC}_{50 \mathrm{~s}}$ of $450 \mathrm{~nm}$ to $22.1 \mu \mathrm{M}$ against the ErmC methylase. No structural similarities were apparent among them which might indicate their mode of action. Nor were these compounds known to be inhibitors of methylase enzymes or ribosome components. Many of these compounds were highly specific for the Erm methylase, producing little or no inhibition of COMT or the EcoRI methylase (Table 2). Note that the $\mathrm{IC}_{50 \mathrm{~s}}$ of the ErmC methylase are expressed in $\mu \mathrm{M}$ concentrations, while the $\mathrm{IC}_{50 \mathrm{~s}}$ for COMT and the $E c o R$ I methylase are expressed in $\mathrm{mM}$ concentrations. CP-112,842-03 and UK-80,882 were the least selective, being 50 and 6.2 times more inhibitory for the ErmC methylase than for COMT, respectively. Only CP117,519-01 produced any inhibition of the EcoRI methylase, generating an $\mathrm{IC}_{50}$ of $800 \mu \mathrm{M}$. Increasing concentrations of AdoMet in the Erm methylase assay did not affect the $\mathrm{IC}_{50 \text { s }}$ of any of these compounds, suggesting that their inhibition was not due to competition for the AdoMet site on the enzyme (data not shown). UK-105,730 was among the most potent, producing an $\mathrm{IC}_{50}$ of $450 \mathrm{~nm}$ against the Erm methylase while the $\beta$-lactam, CP-29,474-22 was the least potent, with an $\mathrm{IC}_{50}$ of $22.1 \mu \mathrm{M}$.

The MIC of these inhibitors for a panel of known $\mathrm{MLS}_{\mathrm{B}}$-resistant bacterial strains was determined (Table

Table 1. Chemical structures of ErmC methylase inhibitors.<smiles>Cc1c2ccncc2c(C)c2c1[nH]c1ccccc12</smiles>

CP-3025 (Replaces P 3025)<smiles>O=c1c2cc(O)c(O)cc2c2cc(O)c(O)cc2n1Cc1ccc(Cl)c(Cl)c1</smiles>

CP-112842-3 hemihydrate<smiles>COc1cccc2c1C(=O)c1c(OC)c(CSC(=N)N)cc(OC)c1C2=O</smiles>

CP-117519-1 hydrochloride salt<smiles>CC1(C)SC2C(NC(=O)[C@@H](NC(=O)C#Cc3ccc(NSc4ccccc4[N+](=O)[O-])cc3)c3ccccc3)C(=O)N2[C@H]1C(=O)O</smiles><smiles>NC(=Nc1nc(-c2cc3ccccc3[nH]2)cs1)NCc1ccccc1</smiles>

CP-74932-4 hydrobromide salt

CP-29474-22 triethylamine salt<smiles>OCC1OC(n2cnc3c(NC4CCCC4)ncnc32)C(O)C1O</smiles><smiles>CC(C)c1ccc(NC(=S)N/N=C/c2cc(Cl)cc(Cl)c2O)cc1</smiles> 
Table 2. $\mathrm{IC}_{50 \mathrm{~s}}$ of synthetic agents for the ErmC methyltransferase, the cathechol-O-methyltransferase and the EcoR I methyltransferase.

\begin{tabular}{lccc}
\hline Compound & $\begin{array}{c}\text { ErmC methyltransferase } \\
\mathrm{IC}_{50}(\mu \mathrm{M})\end{array}$ & $\begin{array}{c}\text { Catechol- } O \text {-methyltransferase } \\
\mathrm{IC}_{50}(\mathrm{mM})\end{array}$ & $\begin{array}{c}\text { EcoR I methyltransferase } \\
\text { IC }_{50}\left(\mathrm{mM}^{\prime}\right)\end{array}$ \\
\hline P-3025 & 4.1 & $>1.0$ & $>1.0$ \\
$\mathrm{CP}-29,474-22$ & 22.1 & $>1.0$ & $>1.0$ \\
CP-74,932-04 & 0.75 & $>1.0$ & $>1.0$ \\
CP-112,842-03 & 0.9 & 0.045 & $>1.0$ \\
CP-117,519-01 & 6.6 & $>1.0$ & 0.800 \\
UK-80,882 & 63 & 0.390 & $>1.0$ \\
UK-105,730 & 0.45 & $>1.0$ & 0.0 \\
Sinefungin & 5.0 & 2.0 & 0.080 \\
\end{tabular}

Table 3. Checkerboard synergy MIC determinations in BHI broth $(\mu \mathrm{g} / \mathrm{ml})$.

\begin{tabular}{clcccccc}
\hline Bacterial strain & P-3025 & CP-29,474-22 & CP-74,932-04 & CP-112,842-03 & CP-117,519-01 & UK-80,882 & UK-105,730 \\
\hline S. aureus 01A110 & $6.2 / 0.39$ & $>25 />25$ & $3.1 / 0.39$ & $>25 />25$ & $>25 />25$ & $0.78 / 0.39$ & $3.12 / 12.5$ \\
& $6.2 />50$ & $>50 />50$ & $3.1 />50$ & $>50 />50$ & $>50 />50$ & $1.5 />50$ & $6.25 / 50$ \\
S. aureus 01A129 & $6.2 / 0.39$ & $>25 />25$ & $3.1 / 0.39$ & $>25 />25$ & $6.2 / 12.5$ & $0.78 / 0.39$ & $1.5 / 1.5$ \\
& $6.2 />50$ & $>50 />50$ & $3.1 />50$ & $>50 />50$ & $>50 / 50$ & $0.78 />50$ & $>50 />50$ \\
E. faecalis 03A1029 & $3.1 / 0.39$ & $6.25 / 0.78$ & $6.2 / 0.39$ & $>25 />25$ & $0.39 / 25$ & $3.1 / 0.39$ & $12.5 / 0.39$ \\
& $3.1 />50$ & $6.25 />50$ & $6.2 />50$ & $>50 />50$ & $>50 / 50$ & $6.2 />50$ & $50 />50$ \\
E. faecalis & $6.2 / 0.39$ & $1.56 / 1.56$ & $6.2 / 0.39$ & $>25 />25$ & $>25 />25$ & $3.1 / 0.39$ & $12.5 / 0.78$ \\
RH110 (Tn9164E) & $6.2 />50$ & $1.56 />50$ & $6.2 />50$ & $>50 />50$ & $>50 />50$ & $1.5 />50$ & $25 />50$ \\
GBS COH31-46 & $3.1 / 0.39$ & $<0.39 /<0.39$ & $6.2 / 0.39$ & $>25 />25$ & $25 / 25$ & $0.78 / 0.39$ & $12.5 / 0.39$ \\
(Tn9164E) & $3.1 />50$ & $<0.20 />50$ & $6.2 />50$ & $>50 />50$ & $50 />50$ & $0.78 />50$ & $25 />50$ \\
E. coli 854 MLS B $_{\mathrm{B}}$ & $6.2 / 0.39$ & $6.25 / 1.56$ & $6.2 / 0.39$ & $>25 />25$ & $>25 />25$ & $>25 />25$ & $>25 />25$ \\
& $6.2 />50$ & $12.5 />50$ & $12.5 />50$ & $>50 />50$ & $>50 />50$ & $>50 />50$ & $>50 />50$ \\
\hline
\end{tabular}

For each strain, the top row of numbers is the concentration of the test compound plus the concentration of azithromycin that produce an MIC. The bottom row is the MIC of the compound alone/MIC of azithromycin alone.

3). In these assays, the MIC of the inhibitor in combination with the macrolide, azithromycin, was compared to the MIC of the inhibitor alone and azithromycin alone. CP-29,474-22, did not inhibit the $\mathrm{MLS}_{\mathrm{B}}$-resistant staphylococcal strains, but was active against the enterococcal and Group B streptococcal strains. It was also moderately active against the recombinant $E$. coli strain expressing $\mathrm{MLS}_{\mathrm{B}}$ resistance. Azithromycin did not have a synergistic effect on the potency of CP-29,474-22 against these strains. CP117,519-01 showed synergistic or additive activity with azithromycin against $S$. aureus $01 \mathrm{~A} 129$ and E. faecalis $03 \mathrm{~A} 1029$ in the assay. In contrast, ErmC inhibitors P-3025 and CP-74,932-04 were active as single agents against each of the bacterial strains. Both compounds had MICs of 3.1 to $6.25 \mu \mathrm{g} / \mathrm{ml}$, and neither had a synergistic or additive effect with azithromycin. This was an unexpected result, since inhibition of the ErmC methylase would not a priori be expected to inhibit the growth of bacterial cells expressing this enzyme. Although these compounds did not inhibit the bacterial
EcoRI methylase, which methylates an internal adenine residue within a specific hexanucleotide palindromic sequence on DNA, it is possible that they inhibit other bacterial transmethylases and that this effect is responsible for their potency as single agents. P-3025 and CP74,932-04 were also inhibitory to macrolide-sensitive bacterial strains (data not shown). Since their effect on these strains could not have been due to inhibition of ErmC methylase, these inhibitors must have additional effects on bacterial cells. Sinefungin produced no inhibition in these assays, presumably because it was not able to penetrate into bacterial cells (data not shown).

Some of the selective ErmC methylase inhibitors that showed in vitro activity against Staphylococcus aureus were evaluated for activity against a generalized, fatal infection in mice caused by a Staphylococcus aureus strain, 01A129, expressing inducible $\mathrm{MLS}_{\mathrm{B}}$-resistance. None of these compounds protected mice at subcutaneous doses of $\leq 100 \mathrm{mg} / \mathrm{kg}$. CP-29,474-22 was not active in vitro against staphylococcal strains, but showed activity against enterococcal and streptococcal 
Table 4. Parenteral protective dose $50\left(\mathrm{PD}_{50}\right)$ determinations.

\begin{tabular}{|c|c|c|}
\hline \multirow[b]{2}{*}{ Compound } & \multicolumn{2}{|c|}{$\mathrm{PD}_{50}(\mathrm{mg} / \mathrm{kg} /$ dose $)$} \\
\hline & $\begin{array}{l}\text { S. aureus } \\
\text { (01A129) }\end{array}$ & $\begin{array}{c}\text { S. pyogenes } \\
\text { (ATCC 12384) }\end{array}$ \\
\hline P-3025 & $>100$ & $\mathrm{NT}^{*}$ \\
\hline CP-29,474-22 & NT & $29.2^{* *}$ \\
\hline CP-74,932-04 & $>100$ & NT \\
\hline UK- 80,882 & $>100$ & NT \\
\hline UK-105,730 & $>100$ & NT \\
\hline Vancomycin & 14.8 & NT \\
\hline Azithromycin & $>100$ & $<1.56$ \\
\hline
\end{tabular}

* No test.

** $\mathrm{MIC}=3.1 \mu \mathrm{g} / \mathrm{ml}$.

strains. It was progressed to a $\mathrm{PD}_{50}$ determination in a mouse model of infection with a macrolide-susceptible $S$. pyogenes strain, and produced a $\mathrm{PD}_{50}$ of $29.2 \mathrm{mg} / \mathrm{kg}$ (Table 4). This $\beta$-lactam derivative was shown in separate experiments to have in vitro potency against several $\beta$-lactam-resistant bacterial strains, suggesting that it had additional modes of action against bacterial cells (data not shown).

It is relevant to considerations of the effectiveness of putative Erm methylase inhibitors to observe that Erm enzymes in the cell are maintained at relatively low levels by two independent regulatory mechanisms. Where they are inducible, it has been shown that one level of regulation occurs at the level of the ribosome by a process called translational attenuation ${ }^{17}$. However, in recent years in areas where macrolide use has increased many $\mathrm{MLS}_{\mathrm{B}}$-resistant strains have become constitutive, which usually occurs by a deletion in the $5^{\prime}$ regulatory region ${ }^{5)}$. A second aspect of regulation may limit the production of methylase in cells with both inducible and constitutive MLS $_{\mathrm{B}}$-resistance. It has been observed that expression of the protein is autoregulated at the level of its own translation, and that certain methylase-deficient variants of ErmC with mutations in the structural gene overproduce truncated forms of inactive methylase. This is consistent with a model in which active methylase regulates its own production by a feedback regulatory loop. The net effect of this is to bring the number of methylase molecules in the cell to a steady state which is approximately equal to the number of ribosomes per cell, $2 \sim 3 \times 10^{418)}$. Competitive or non-competitive inhibitors of enzymes produced constitutively would have to be present in higher concentrations to be effective. One hundred and sixty thousand synthetic compounds were screened and small-molecule inhibitors of various structural types were identified as specific inhibitors of the dimethylation of $23 \mathrm{~S}$ rRNA catalyzed by the ErmC methylase. Four of these had $\mathrm{IC}_{50 \mathrm{~s}}<5 \mu \mathrm{M}$ and appeared to have little or no inhibitory activity against two unrelated methyltransferases. Some of these were able to penetrate into Gram-positive, and sometimes into Gram-negative, $\mathrm{MLS}_{\mathrm{B}}$-resistant bacterial strains and inhibit growth (Table 3), either alone or in synergy with a macrolide. Although most of these compounds had no activity in mouse models of infection, they represent synthetic leads which may be utilized to design more potent, selective agents with pharmacokinetic properties suitable for use in human disease.

\section{Acknowledgments}

We thank Edward E. Mena and June B. Daffeh for additional preparations of ErmC methylase and Katherine Brighty for chemical analysis of file compounds. We also thank Claudio D. Denoya for providing protocols for the purification of the ErmC methylase, the ErmC-producing strain, and for many useful discussions.

\section{References}

1) CundlifFe, E.: Recognition sites for antibiotics in rRNA. The Ribosome. Eds., W. E. Hill, A. Dahlberg, R. A. Garrett, P. B. Moore, D. Schlessinger and J. R. WARNER, pp. 482 483, ASM Publications, 1990

2) Ballesta, J. P. G. \& E. Lazaro: Peptidyltransferase inhibitors: structure-activity relationship analysis by chemical modification. The Ribosome. Eds., W. E. HiLL, et. al., pp. 505 506, ASM Publications, 1990

3) Weisblum, B.: Erythromycin resistance by ribosome modification. Antimicrob. Agents Chemother. 39: 577 585,1995

4) Weisblum, B.: Insights into erythromycin action from studies of its activity as inducer of resistance. Antimicrob. Agents Chemother. 39: 797 805, 1995

5) LeClerce, R. \& P. Courvalin: Bacterial resistance to macrolide, lincosamide, and streptogramin antibiotics by target modification. Antimicrob. Agents Chemother. 35: $1267 \sim 1272,1991$

6) Arthur, M.; C. Molinas, C. Mabilat \& P. Courvalin: Detection of erythromycin resistance by the polymerase chain reaction using primers in conserved regions of erm rRNA methylase genes. Antimicrob. Agents Chemother. 34: $2024 \sim 2026,1990$

7) Denoya, C. D. \& D. Dubnau: Site and substrate specificity of the ermC 23S rRNA methyltransferases. J. Bacteriol. 169: 3857 3860, 1987

8) Shivakumar, A. G. \& D. Dubnau: Characterization of a plasmid-specified ribosome methylase associated with macrolide resistance. Nucleic Acids Res. 9 (11): $2549 \sim 2562,1981$

9) Denoya, C. D. \& D. Dubnau: Kinetic studies of the ermC rRNA methyltransferase, J. Biol. Chem. 264: 2615 2624, 1989

10) Su, S. L. \& D. Dubnau: Binding of Bacillus subtilis 
ermC $C^{\prime}$ methyltransferase to 23S rRNA. Biochemistry 29: $6033 \sim 6042,1990$

11) Weisblum, B.; M. Y. Graham, T. Gryczan \& D. DUBNAU: Plasmid copy number control: isolation and characterization of high-copy-number mutants of plasmid pE194. J. Bacteriol. 137: 635 643, 1979

12) Rubens, C. E. \& L. M. Heggen: Tn916 E: a Tn916 transposon derivative expressing erythromycin resistance. Plasmid 20: $2137 \sim 2142,1988$

13) Macrina, F. L.; J. A. Tobian, K. R. Jones, P. Evans \& D. B. Clewell: A cloning vector able to replicate in Escherichia coli and Streptococcus sanguis. Gene 19: $345 \sim 353,1982$

14) Ausubel, F. M.; R. Brent, R. Kingston, D. Moore, J. Smith, J. G. Seidman \& K. Struhl: Current Protocols in Molecular Biology. pp. 2.5.5, John Wiley \& Sons, 1989

15) Balows, A.; W. J. Hausler Jr., K. L. Herrman, H. D.
Isenberg \& H. J. Shadomy: Manual of Clinical Microbiology. Fifth Edition. p. 1159, ASM Publication, 1991

16) English, A. R.; J A. RetSEMA \& J. E. LyNCH: Laboratory evaluation of 3-(5-tetrazoyl)penam, a new semisynthetic B-lactam antibacterial agent with extended broadspectrum activity. Antimicrob. Agents Chemother. 10: $132 \sim 138,1976$

17) Weisblum, B.: Inducible resistance to macrolide, lincosamide and streptogramin B antibiotics: the resistance phenotype, its biological diversity, and structural elements that regulate expression-a review. J. Antimicrob. Chemother. 16 (Suppl. A): 63 90, 1985

18) Denoya, C. D.; D. H. Bechhofer \& D. Dubnau: Translational autoregulation of ermC 23S rRNA methyltransferase expréssion in Bacillus subtilis. $\mathbf{J}$. Bacteriol. 16: 1133 1141, 1988 